ん。此例でいへば著者は普通之を Lm. 又は Lms. と署いて居るが猪狩氏は Lum. 或は Lums. を支持せられる样である。更て André Blondel の諭文を見るとてれが lu となつて居る。 誠に多種多橉百花繚㦨の形でする。

斯くの如きものも統一されたらお互に便利ではあるまいかと考へ茲に提議する次第である。

5. 餘錄 最後に Blondel 敉授の論文 Sur les grandeurs et unités photométriques. Le système photométrique C.G.S.(R.G.E. Tome 23, No. 26. 30 Juin, 1928, pp. 1099-1103) から 衍語の記號と單值の略字とをとり出して表示する。

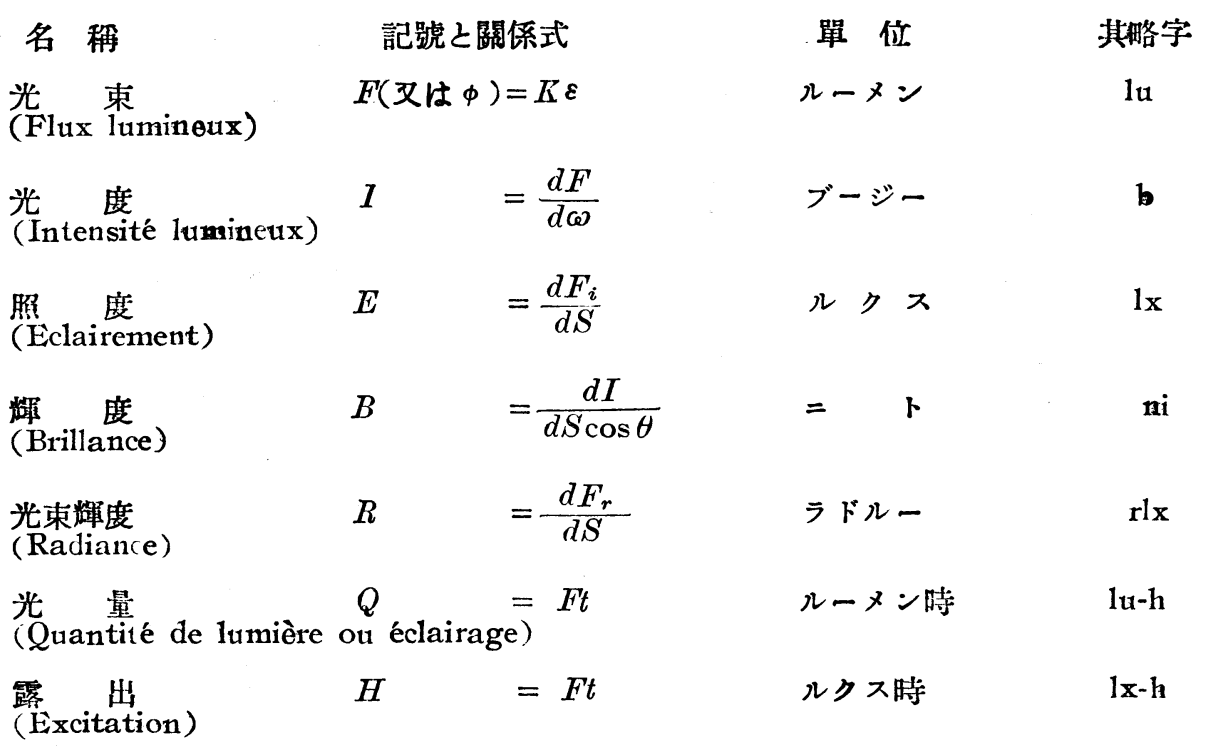

但し $F_{i}$ は入射束, $F_{r}$ は輻射束, $\varepsilon$ はェネルギー, $\omega$ は立體角, $K$ は生理學的恒數， $S$ は 面積

\title{
正 誤
}

第十二卷第六號 論镜『布地及び輻射熱缐に

對する性質』に對する正誤表

\begin{tabular}{|c|c|c|c|}
\hline 頁 & 行 & 誤 & 正 \\
\hline 325 & $1-2$ & $\begin{array}{l}\text { 寫嗔が即ちそ } \\
\text { れである。 }\end{array}$ & 制 \\
\hline 326 & $\begin{array}{l}\text { 第 } 2 \text { 圖及第 } \\
3 \text { 圖の說明 }\end{array}$ & $\begin{array}{l}\text { 率の scale は } \\
\text { 第一圖に同じ }\end{array}$ & $\begin{array}{l}\text { 金鋼の場合は實測値 } \\
\text { の } 1 / 10 \text { に示してある }\end{array}$ \\
\hline
\end{tabular}

